\section{NEWS AND VIEWS FROM THE SCIENTIFIC FRONT*}

\author{
By SIR RICHARD GREGORY, BART., F.R.S.
}

\begin{abstract}
TN the middle of last century, contemporary 1 thought was no more ready to receive, or able to understand, Darwin's scientific evidence as to man's place in Nature than philosophers and theologians of Galileo's time were willing to be convinced of the truth of his observations and the rational conclusions derived from them. When the "Origin of Species" was published the review copy sent to The Times was handed to a member of the staff who was responsible for notices of literary works generally. $\mathrm{He}$ was an excellent journalist but as innocent of science as a child, so he exercised editorial functions and asked a friend to suggest someone who could write a review which he could adopt with a few introductory remarks of his own. Fortunately, T. H. Huxley undertook to do this, and his fine article on Darwin's book appeared in The Times unsigned in the usual way. It was not until later that he permitted it to be known that he was the author of the review.
\end{abstract}

At that time the Saturday Review devoted a fortnightly column to scientific subjects, and this led Huxley to believe that a quarterly magazine surveying advances of science in a systematic way was wanted, particularly on account of the poor state of natural history journalism. He therefore became chiefly responsible for the launching of the Natural History Review in January 1861 and continued as its overworked and unpaid editor for two years. $\mathrm{He}$ then ceased to contribute to the magazine, but the publisher, Mr. John Murray, decided to carry on with paid contributors and editors instead of volunteers. As, however, the enterprise was never sound financially, there was little hope for it under the new scheme and the magazine came to an end in 1865 .

The promise of success of a quarterly review for general scientific readers, whether devoted to the biological or the physical sciences or to both, is no better to-day than it was then. Most scientific and technical societies provide facilities for keeping their members in touch with advances in their own professional spheres, but their vocabularies are usually so highly specialized that they are unintelligible without preliminary acquaintance with their meaning. After the Natural History Review had failed to find a sufficient circulation to maintain its publication in quarterly issues, a weekly periodical of a less specialized kind, The Reader, was started and Huxley took an active part in conducting it, until it also came to an end after a life of three or four years only.

J. Norman Lockyer, who was the science editor of The Reader during its existence, as well as a contributor to the Saturday Review and other nonprofessional periodicals, was led by his experience to the conclusion that a weekly journal of science of a more comprehensive scope than any previously published was needed by both scientific and general readers. He was at that time scientific adviser to the Macmillan firm of publishers, and the head of it, Mr. Alexander Macmillan, believing that the interests of science and of the British people would be advanced by such a journal, warmly supported plans

- Substance of an address at the Conference on Science and the Citizen held under the auspices of the British Association Division for the Social and International Relations of Science in London on March 20-21. for its establishment. All the leading contemporary men of science promised active co-operation in Lockyer's scheme, the result being that the first number of NaTURE appeared on November 4, 1869, with Messrs. Macmillan as the publishers [see also NATURe of February 27, p. 231].

In that period public attention was being directed to scientific subjects in the general Press and other periodicals. A weekly International Review of Scientific Lectures, published in Paris, was devoted to public lectures delivered by leading scientific authorities in the chief countries of the world, thus enabling general readers, as well as men of science, to become acquainted with the advances being made. A few weeks before Nature was published, Mr. John Murray began the issue of the Academy, "a monthly record of literature, learning, science and art". Prof. Huxley and Sir John Lubbock were among the scientific contributors to the first number. Though the Academy gave particular prominence to scientific subjects, and included in its second number several papers by Helmholtz, Mayer, Virchow and other men of science read at a meeting of the German Association of Naturalists at Innsbruck, as well as summaries of other communications, it did not become a rival to Nature, as was feared it might do, and friendly relations were always maintained between the two editors.

What Lockyer desired to do was to promote public interest in science and its achievements, whether through the general Press, lectures, or in any other useful way. The more contacts he could find between science and the public mind, the better he was pleased. With Huxley and Tyndall he combined scientific authority with literary power, and represented, therefore, the most effective type of connecting link between science and the citizen, whether through articles or in popular lectures. It was to assert the rights of science to an honoured place in national service, as well as its responsibilities to the develop. ment of natural resources, both intellectual and material, that NATURE was founded.

The establishment of a weekly periodical to promote public understanding of science, and at the same time to provide a forum for natural philosophers, was a notable event in the history of journalism. It is true that, nearly forty years earlier, the British Association was founded with much the same intentions, but as it met in full session only once annually, accounts of its activities in the periodical Press were limited to a few issues.

The attitude of the public Press, when the founders of the Association charged themselves with the obligations "to obtain more general attention for the objects of Science" and held annual meetings in different parts of the country for this purpose as well as for the discussion of scientific advances, was the reverse of encouraging. It was represented in contemporary journalism by Dickens' articles in Bentley's Miscellany, afterwards published as the "Mudfog Papers". These contributions were caricatures of the proceedings of the first and second meetings of the Association and of the men of science who took part in them. Less crude, but just as derisive, views as to the meaning of science and its service to the community prevailed in literary circles generally. The Times ridiculed the Association and its objects at the beginning and continued to do so for a number of years afterwards. It and other journals of the time, like The Age and John Bull, regarded the entrance of science into public life as an intrusion, 
and its efforts to extend the understanding of it as evidence of a desire for self-advertisement.

By the middle of the century, however, contempt had changed to condescension, and the public mind was ready to give sympathetic consideration to the utterances and publications of what had been described as a "hodge-podge of philosophers" by such a cultured representative of higher learning as John Keble of Oxford. Even though the tone of literary scholars and leaders of the Press towards scientific work and thought continued to be supercilious, the new humanism made a strong appeal to many progressive minds, and leading organs of the Press introduced its chords into their harmony of news.

When NaTURE made its first appearance, the period of opposition to organized science and its public relationships had been left behind. From being regarded as presumptively vociferous, the natural sciences came into positions of authority among the progressive elements of human thought and action. The Great Exhibition of 1851 and the second International Exhibition held eleven years later had given new outlooks to industrial science and its profitable development. Labour asserted its rights to a place in the economic field by the formation in 1864 of the International Working Men's Association, which afterwards became "The International". To guardians of traditional learning and social privileges, both science and labour represented revolutionary movements which had to be admitted into the fields of public affairs even though their motives and purposes did not approach the conventional standards of Victorian respectability. The common cause was to secure freedom of thought and action and the advancement of human welfare.

The periodical Press took critical or helpful attitudes towards these claims, each reflecting the views of most of its readers and some using a lens instead of a mirror to examine them. In order to exist, a journal, like a human being, must have a good circulation as well as a heart to keep the living stream in full flow. In journalism many hopeful hearts have believed that a large body of the public was waiting to respond to their strong and steady throbbing, but have been doomed to disappointment. Sooner or later, the public, general or special, gets the kind of journal it wants, and decides whether or no its publication is worth while financially. From a business point of view, lack of sufficient support is more often due to being in advance of the times than lagging behind them.

In the 'sixties of last century scientific forces formed the spearhead of cultural movement; but though their main advances compelled attention they broke up an established system of defence and received, therefore, little support from other elements in the front line. In the absence of accurate and intelligible accounts of operations in scientific fields, neither the public nor its leaders could arrive at a right understanding of their meaning or justly judge the value of the resources of the new territory of natural knowledge. There was need for the organization of scientific intelligence and also for the expression of scientific opinion upon educational and other public problems then under discussion. The time had come for performance to be related to progressive policy and science to exert its influence in the realm of the Fourth Estate. It was with the object of presenting news of advances in the expanding field of natural knowledge and of expressing the views of leaders in the scientific services on contacts of such knowledge with current questions in which it was an important factor, that NATURE was founded.

The entrance of scientific 'usurpers' into the fields of public policy and established learning met with a hostile reception, but it was welcomed by enlightened leaders in other cultural groups. The moment was opportune to make their advances and influence known to all who cared to give attention to them, even though the promise of support was relatively small. Confidence in a cause has to be sustained if success is to be achieved, and it was needed to found and maintain a weekly scientific journal in the third quarter of the nineteenth century, when education in science had a very minor place in the schools. At that time interest as well as enterprise were required to establish a periodical of this kind. Fortunately, Mr. Alexander Macmillan, who was then the head of the great house of publishers bearing his name, possessed these qualities and maintained his faith in the mission of science without consideration of financial profits to be derived from the publication of its weekly message. It was not until towards the end of his life in 1896 that NATURE became selfsupporting, though from the beginning the journal was esteemed as the accredited organ of scientific fact and opinion.

One of the reasons for the long-delayed fulfilment of early promise was the increase of specialization among scientific workers. In the quarter of a century following 1869, nearly fifty separate societies were founded, each dealing with a particular department of science or technology, all of them issuing publications of a special kind, and some having their own journals. It became difficult to keep in close contact with developments in even a single field of operations, and more so for workers in other fields to understand the terms in which advances were described. The forces in the front line 'ost touch with one another, but each continually entered new territory and established strong positions in it. The common purpose of the pioneer corps was to clear away the tangled growth which obscured most of the features of Nature and to explore what was beneath it. The object of the technical services which occupied the territories acquired was to examine the resources in them and apply discoveries to useful ends.

Among the journals in existence before Nature made its first appearance were the Lancet, British Medical Journal, Chemist and Druggist, Electrician, Engineer, Engineering, Gardeners' Chronicle, English Mechanics (now Mechanics), and Pharmaceutical Journal. A journal which aimed at recording notable movements along the whole line of advance of pure and applied science in terms intelligible to all of them as well as to non-professional readers with wide interests had to undertake the duties of an intelligence department with the policy of a general staff.

For more than fifty years, the general staff responsible for the conduct and contents of NATURE consisted of two officers - an editor and an assistant editor. Correspondents from all parts of the world made the journal a centre of scientific news and views from the very beginning of its foundation. The increase in numbers of scientific and industrial research centres led to a greatly increased volume of original communications from them. The result was that NATURF became a kind of clearing-house at which scientific drafts were presented and their exchange values adjusted. In a single year before the present War, nearly one thousand letters from original 
investigators appeared in the correspondence columns of the journal. One sixth of these letters were from scientific centres outside the British Isles, and thirty different countries were represented by their writers. The journal thus came to be recognized as a world medium in which early announcements could be made of new scientific observations and conclusions.

By providing the means of expansion of old in. dustries and creating new, science has transformed conditions of civilized life and influenced the whole social structure. In Darwin's days beams from strong scientific searchlights revealed weak parts of ancient bulwarks which were believed to be impregnable. The beams came from a lighthouse and were not produced for purposes of aggressive action by new forces but for the guidance of mariners in mysterious seas. They were, however, so dazzling in their effects that they were resented as a danger to established principles of navigation instead of being welcomed. The conflict which then arose was between champions of new and old ways of looking upon humañ life in its philosophic and spiritual aspects. Later, the cry of danger was again raised against science because poison gases, high explosives and bombs from aeroplanes were among its fruits. The War of 1914-18 brought this attitude towards science into prominence, and the view was expressed by responsible leaders of thought that a halt should be called to further advance of knowledge because of the dehumanizing results which might be derived from them. By this time, however, there was a sufficient body of responsible opinion to assert the right of science not only to liberty of thought and action in its own fields, but also to be a component part of the executive staffs in control of the disposition of its forces.

The campaign with these objects in view as well as to establish closer contacts between science and other formative elements in the social structure was opened in NATURE of October 21, 1915, with a leading article on "Science in National Affairs". Every week since then the journal has had the temerity to express opinions upon current affairs in which scientific methods and services are involved. Without entering the field of party politics there has never been a lack of important public problems requiring scientific knowledge as well as wisdom for their right solution.

The result of the revival of the scientific movement has been to give the social and international relations of science both shape and policy. In 1938, the British Association established an autonomous Division of its constitution to promote these objects, which were among its original purposes. There are still many people who regard men of science as members of a kind of monastic order content to carry on their studies in cloistered seclusion, whether their lives and work are of service to others or not. The history of science is rich in examples of men of this type, pursuing knowledge for its own sake without thought of recognition in this world or reward in another. They are the saints of science and are revered as such by all who esteem truth and the high endeavour its pursuit entails. To these natural philosophers, the impressive fabric of science owes the main features of its design and execution; and no tribute is too great to be paid to them.

Science is, however, a gospel of righteous principles however much they may be departed from in practice. It has the duty not only of preparing messages but also the mission of interpreting their meaning to all who will give attention to them. In the history of civilization there has never been an epoch in which understanding of the spirit and service of science was more necessary for the public and its leaders than now. A century ago wide public interest was aroused in scientific subjects through descriptive lectures with experimental and other illustrations, but there is far less demand in these days for the expositions which were then so popular. The cinema and broadcasting can now perform this informative function much more effectively than peripatetic lecturers. What the public is ready to take active interest in to-day is the impact of science upon social conditions, and its relations to life and labour. These are subjects upon which any individual citizen affected by them can have his own opinion and is at liberty to express it. The function of science at a public conference or meeting is to present the results of impartial inquiry into any such subject for which a meeting is convened and to provide whatever further information is available relating to it.

The British Association, through its Division for the Social and International Relations of Science, could most appropriately organize such public conferences at suitable centres anywhere in Great Britain, and by doing so would greatly assist in the extension of knowledge of contacts between the natural and the social sciences. It could do at home what the British Council is doing for science and other fields of culture abroad, but to undertake such an educational enterprise successfully would require much greater financial support than the Association is at present able to provide. If this Conference on "Science and the Citizen". should lead to the establishment of a kind of public university extension movement, with particular reference to science and social values, it would mark the beginning of a new era of constructive co-ordination of progressive sciontific know. ledge with changing social needs.

\section{THE CONCEPT OF ENERGY}

\section{By Dr. A. E. BELL Bradfield College}

T $\mathrm{N}$ an earlier article entitled "Modern Science and Thomas Hobbes", I remarked that it was especially the law of conservation of energy which inclined thinkers of the nineteenth century to a rigid determinism. The concept of energy gained such great prestige during the latter half of that century that it seemed as if physics were as much preoccupied with energy as the chemists were with matter. Although that era is gone and the historian of the relativity theory will have to show how the two fields became less completely demarcated, the old categories of thought still remain, and for many purposes perhaps they always will. In any event the concept of energy in classical physics holds much the same central position that the atomic theory holds in chemistry-but there are no comparable historical studies.

One hundred years ago, Sir William Robert Grove gave a course of lectures at the London Institution, later published (in 1846) under the title "On the Correlation of Physical Forces". In these lectures Grove pointed, for the first time, to the interconversion of various physical 'forces' and argued the existence of some underlying identity ; in essence he gave a formulation of the general law of conservation of energy. The full importance of Joule's paper of 